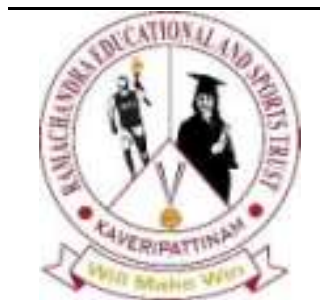

Contemporaneity of Language and Literature in the Robotized Millennium

Vol: 3(1), 2021

REST Publisher

ISBN: 978-81-936097-3-6

Website: http://restpublisher.com/book-series/cllrm/

\title{
A Review Article on the Challenges in Teaching Tech Savvy Generation
}

\author{
Dr. S. Jeya Bharathi, \\ St. Mary's College (Autonomous), Thoothukudi, Tamil Nadu, India. \\ Email: aathini81@gmail.com
}

\begin{abstract}
This review paper summarizes the recent researches done on the challenges faced in teaching the tech savvy generation. The author has categorized the review under 3 topics: Teacher challenges, Student experience and Teaching learning processes and outcome. The author has chosen to review 20 research papers that were strikingly strong in methodology and research findings. They were also the papers that grabbed the interest and curiosity of the author. The studies confirm a common concept that the teachers have been expected to stretch a lot to teach using technology based methods. They also state that on the whole, most of the teachers have mastered the task. Few studies also highlight the difficulties faced by the so called tech savvy students. A lot of studies are yet to be done on the quality of learning outcomes of the prevailing technology based education system. Now that things are returning to normalcy, more research has to be done also in the graceful returning to offline teaching environment where technology will continue to play a prominent role in the teaching and learning process.
\end{abstract}

Key words: Challenges, Online teaching, Technology, Teachers, Students

\section{Introduction}

Things are not the same as they used to be two years back. Educational set up, mode of knowledge transfer, the materials used in the teaching learning process, the evaluation pattern, the teacher-student relationship and even the attitude towards the process of gaining knowledge has changed. From white boards to smart boards and text books to laptops, technology has changed so much in the field of education. This technology has brought about a knowledge revolution amongst the learners whose participation has doubled as a result of inculcating technology in the curriculum (Pearson, 2017). Education is not just about gaining knowledge. It is also about developing social skills and sportsmanship. The developments of these attributes have been severely hindered as a result of online teaching and learning. This in turn toughens the challenges of teaching the tech savvy generation. Also in a country like India, technology enhanced education may not be possible for a large population due to socio economic reasons which leads to a sharp discrimination among the students community (Karyala P, Kamat S., 2020)

\section{Need for the study}

Although a lot is being discussed these days on this topic and a lot of researches are initiated in these areas, it is essential for us to take a breath and synthesise everything. This will help us identify the areas that are to be explored more and also provide us the clarity of the steps to be taken based on the research results obtained. This has lead to the need for the current study. The author has chosen to review 20 research papers that were strikingly strong in methodology and research findings. They were also the papers that grabbed the interest and curiosity of the author. The discussions and conclusion provided by the author will pave way for future research in this area.

\section{Methodology}

The author has meticulously searched for articles from the recent past that have been done on the online education and its impact on the teaching and learning process. The 20 articles chosen from the reviewed articles have been categorized under 3 topics: Teacher challenges, Student experience and Teaching learning processes and outcome. The author has chosen to review 20 research papers that were strikingly strong in methodology and research findings. These review articles have been analyzed and discussed by the author to come up with some authentic research findings.

\section{Teacher challenges}

A study by Rosalina E (2020) clearly explains the threat the pandemic has posed on the teachers. It was very unfair to expect the teachers to get upgraded all of a sudden. But it is highly appreciable that most of the teachers were able to cope up with the demands of the situation. Aram H., et. al. (2021) did a study on Public Universities, Karachi Pakistan to identify the challenges faced by the teachers in online teaching. The result of the study concluded that although most of the faculty was able to cope up, the main challenge they faced was the lack of technical support and training they received from the management. A study done by Frazer C. (2017) however, states the positive side of online teaching. This study done on nursing tutors states that many teachers were motivated to be better teachers as they felt motivated by the feedback they received from their students. Exploring the technology and mastering it, gave an immense sense of 
accomplishment among the teachers. A study done on 192 public secondary school teachers by Izhar N.A., et.al. (2021) has helped identify the 8 challenge areas of teachers. They are: time, environment, technological access, interest, knowledge, technological skills, course design and communication self-efficacy. Schrum L (2008) did a study to understand the Tech savvy teachers, their challenges and motivations. The results indicate that the use of technology gave a feeling of professionalism among the teachers and feel good attitude towards their performances. And it was all about the efficiency to grasp the new skill of implementing technology in the teaching learning process. Hwang J.M. (2011) submitted a report on the usage of specific technologies in teaching by the contemporary teachers. The report has identified the fact that teachers spend a lot of time initially in choosing the right technology that would suit their course and their teaching style. This increased their performance levels as good teachers.

\section{Student experiences}

The students' experiences in online and virtual mode are varied depending upon their prior experiences and familiarity with technology. A study by Grey J (2017) clearly explains the expectations of tech savvy students. The results declare that the students expect technology that would their multi tasking nature and help save time. In that view, they opt for audio books that are highly engaging and can be used in various devices. Gillett J (2017) did a study on the level of student participation in online teaching learning process. The researcher has found that isolated learners away from the faculty and other classmates find it difficult to cope with the process, especially when it comes to group work and practical oriented learning material. Paul J. and Jefferson F. (2019) did a study on UG students to find out their preferences for online or offline mode of education. It was found that majority of the students opted for online teaching as they felt the traditional teaching method was restrictive, inflexible and not practical. However, the study did not find any difference in the performance levels in online and offline mode of education. Iivari N. Et.al. (2020) did a study on how COVID-19 pandemic transformed the basic education of the young generation. The study revealed the fact that the students were smart enough to cope with the technology teaching and many were found to enjoy the personal space they get to learn on their own. They received ample time for the subjects of their choice and found it challenging. Only few students who didn't have elders at home to guide them suffered. But this constraint was overcome by the extra efforts taken by the teacher. Greenhow C (2007) did an interesting study on the internet usage among low income learners. The study found that the low income learners did not get internet access on daily basis and although they had technology devices of some sort or the other at home, they had to share with their siblings. This lead to time constraint and access constraint for the learners from families with low income.

\section{Teaching - learning process and outcome}

Palvia S. Et.al. (2018) did an extensive study on the worldwide status, trends and implications of online education. The study focused on the pros and corns of online learning. The results declare that online education has taken the educational field to the next level. It also states that by 2025, online education would become the mainstream education. Teachers and students have beautifully adapted to the current trends and excelling in performances. The study also identifies few factors that contribute to the efficiency of online learning like availability of technology and access to it, training, etc. Pandit D. and Agarwal S. in 2021 did a study exploring the challenges of education during COVID times. They propose that there needs to be an Eco System for effective online teaching that would facilitate the teaching learning process. They suggest that few basic requirements have to be satisfied for an effective learning environment. They include academic leadership, collaborative peer learning, know-how of digital technology and online learning tools, training of faculty and readiness of students. Kebritchi M, et. al., in 2016 did a literature review on the opportunities and challenges of online teaching and learning. In their study, they have identified the problems faced by the faculty, students and the problems faced in content development and delivery. To address all the challenges faced, the researchers suggest technical support for content development, proper training for students to use technology for learning and professional development for faculty. Once all this is attained, online education would be bliss. Coman C. ET. al., (2020) studied the teaching and learning process from a student's perspective. According to this study, the greatest challenge of online teaching were the technical issues that they face, the incompatibility of the teachers and their inability to deliver knowledge effectively using online education. Also, the students' inactive nature in online teaching methods also serves as a great barrier that prevents progress.

\section{Author discussion}

The author has analyses the research papers and has come up with discussion that both acknowledges and denies the research results.

\section{Discussion on research related to Teacher challenges}

The papers reviewed by the author threw light on the challenges faced by teachers in this technology driven world where they are expected to educate the tech savvy students. Being a teacher herself, the author agrees with all the challenges discussed in the research papers reviewed right from the struggling to adapt to the online teaching modes to handling the dumb students who don't bother to respond in class. The author admits the lack of proper training and technical support from most of the managements that run the schools or college. When we keep insisting on online mode of education, most of the managements expect the teachers to take of the internet connections themselves. Another important factor not discussed in most of the studies reviewed is the reduced income of the teachers during the pandemic when online teaching came into full swing. Most of the temporary staffs who were receiving management pay were given only half the pay which greatly affected their standard of living. Adding to this, the network connectivity was a burden for many staffs. Also, 
preparing for online classes was a tedious job with all ppts and presentations to be prepared. Another major stress faced by the faculty, especially female teachers was the management between academic work and house work as they had to work from home. Despite all these short comings, the researches have done reveal that many teachers looked at the positive side of on line teaching and showed interest in equipping themselves technically.

\section{Discussion on student experience}

Studies state that students' experience of online education is good on the whole as they are fascinated by the technology involved here. This has changed the traditional boring attitude towards education and gaining knowledge. The studies reviewed state that majority of the students find the technology aided teaching to support their multi tasking capabilities. It was found that majority of the students opted for online teaching as they felt the traditional teaching method was restrictive, inflexible and not practical. But it is also interesting to note that when performance was considered, there was no much difference in performance between online and offline mode. Also there have been found students who report that they are not very technically strong as believed to be. This, as a teacher myself, have witnessed among few of my students. Some students find it very difficult to even do the basic level of tasks like creating a Google form or posting an assignment in the Google classroom. These students also often do not reach out for help. Due to the virtual environment there were huge chances for them to be left behind in performances. And in my observation, much management has initiated training programs in technology facilitated education only for faculty and not for students. This has been a major drawback for numerous students. Hence in the future, such hindrances may be removed to improve the quality and performance levels of students in online education.

\section{Discussion on Teaching Learning Process and Outcome}

The teaching learning process has attained a huge revolutionary transformation after the onset of online mode of teaching and learning. This has been proved from the studies that have been reviewed by the author. The studies reviewed all accept the fact that technology has taken education to the next level and if proper training is given for the students and teachers and the network issues are taken care of, technology filled education would be bliss for both the student and the teacher community. Few studies also have done from the student perspective which reveals that they can enjoy online learning only if the faculty is equipped with technical knowledge and expertise.

\section{Conclusion}

The studies reviewed by the author on the topic challenges of teaching tech savvy generation also has extended to related areas like student perspectives and the impact on technology education on the teaching and learning process. Most of the studies have been in line with the author's perspectives as she has also experienced this being a teacher herself. But the surprising fact that has struck her was that many students may not be as tech savvy as they are perceived. This would definitely change her approach towards the handling of students henceforth. Also, the findings that reveal that the majority of the teachers have coped up with the critical situation gives a boost to the author and a reassurance that she isn't alone in this process of learning. This research has given us knowledge on the areas that have been researched and the areas that have to be throbbed into. On that regard, the author suggests research to be focused on the development of all-students' affordable network system and easy and fun training sessions that would help make technology a plate of cake for both the teachers and students.

\section{Reference}

1. Akram H., et. al. (2021) The Challenges Of Online Teaching In Covid-19 Pandemic: A Case Study Of Public Universities In Karachi, Pakistan. Journal of Information Technology Education: Research. Vol 20 Pgs: 263-282 https://doi.org/10.28945/4784

2. Coman C. Et. al., (2020) Online Teaching and Learning in Higher Education during the Coronavirus Pandemic: Students' Perspective. Sustainability 2020, 12, 10367; oi:10.3390/su122410367

3. Frazer C. (2017) Faculty Perceptions of Online Teaching Effectiveness and Indicators of Quality. Hindawi Nursing Research and Practice Volume 2017, Article ID 9374189, 6 pages https://doi.org/10.1155/2017/9374189

4. Gillett J (2017) The challenges of online learning- Supporting and engaging the isolated learner. Journal of learning design. Vol 10, Issue 1, Pgs: 20-29

5. Greenhow C. (2007) Millennial Learners and Net-Savvy Teens? Examining Internet Use among Low-Income Students Volume 26/ Number 2 Winter 2009-10 Journal of Computing in Teacher Education Pgs: 66-68

6. Palvia, S. et.al., (2018) Online Education: Worldwide Status, Challenges, Trends, and Implications, Journal of Global Information Technology Management, 21:4, 233-241,

7. DOI: $10.1080 / 1097198 X .2018 .1542262$

8. Iivari N. Et.al. (2020) Digital transformation of everyday life - How COVID-19 pandemic transformed the basic education of the young generation and why information management research should care? International Journal of Information Management 55 (2020) 102183

9. Izhar, N. A., et.al., (2021). Teaching in the Time of Covid-19: The Challenges Faced By Teachers in Initiating Online Class Sessions. International Journal of Academic Research in Business and Social Sciences, 11(2), 12941306. 
10. Karyala P. \& Kamat S., (2020) Policy, teaching and education. Retrieved from, https://indiabioscience.org/columns/education/online-education-in-india-the-good-the-bad-and-the-ugly

11. Kebritchi M, et. al., (2016) Issues and Challenges for Teaching Successful Online Courses in Higher Education: A Literature Review. Journal of Educational Technology Systems 2017, Vol. 46(1) 4-29

12. Palvia S. Et.al. (2018) Online Education: Worldwide Status, Challenges,

13. Trends, and Implications, Journal of Global Information Technology Management, 21:4, 233-241, DOI: 10.1080/1097198X.2018.1542262

14. Pandit D. and Agarwal S. (2021). Exploring Challenges of Online Education in COVID Times FIIB Business Review 1-8

15. Paul J. and Jefferson F. (2019) A Comparative Analysis of Student Performance in an Online vs. Face-to-Face Environmental Science Course From 2009 to 2016 Vol 1, Article 7 Frontiers in Computer Science doi: 10.3389/fcomp.2019.00007

16. Pearson S., (2017) How to engage tech-savvy students. Retrieved from, https://www.pearson.com/pedblogs/blogs/2017/12/how-to-engage-tech-savvy-students.html

17. Rosalina E (2020). Teacher challenges towards online learning in the pandemic era. Linguistic, literature and English Teaching Journal. Vol 10, Issue 2, Pgs: 71-88

18. Schrum L., et. al., (2008). Understanding tech-savvy teachers: Identifying their characteristics, motivation, and challenges. International Journal of Technology in Teaching and Learning, 4(1), 1-20. 